\title{
Nepheline Nucleation and Crystal Growth In Waste Glasses: Interim Report
}

J.W. Amoroso

September 2011

Savannah River National Laboratory

Savannah River Nuclear Solutions, LLC Aiken, SC 29808

Prepared for the U.S. Department of Energy under contract number DE-AC09-08SR22470. 
SRNL-STI-2011-00549

Revision 0

\section{DISCLAIMER}

This work was prepared under an agreement with and funded by the U.S. Government. Neither the U.S. Government or its employees, nor any of its contractors, subcontractors or their employees, makes any express or implied:

1. warranty or assumes any legal liability for the accuracy, completeness, or for the use or results of such use of any information, product, or process disclosed; or

2. representation that such use or results of such use would not infringe privately owned rights; or

3. endorsement or recommendation of any specifically identified commercial product, process, or service.

Any views and opinions of authors expressed in this work do not necessarily state or reflect those of the United States Government, or its contractors, or subcontractors.

\section{Printed in the United States of America \\ Prepared for \\ U.S. Department of Energy}


Keywords: Nepheline,

Crystallization, DWPF,

Nucleation

Retention: Permanent

\section{Nepheline Nucleation and Crystal Growth In Waste Glasses: Interim Report}

J.W. Amoroso

September 2011

Savannah River National Laboratory Savannah River Nuclear Solutions, LLC Aiken, SC 29808

Prepared for the U.S. Department of Energy under

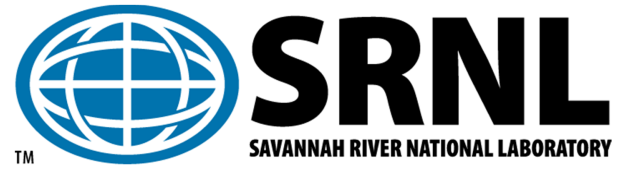
contract number DE-AC09-08SR22470. 
SRNL-STI-2011-00549

Revision 0

\section{REVIEWS AND APPROVALS}

AUTHOR:

J.W. Amoroso, Process Technology Programs

Date

TECHNICAL REVIEW:

K. M. Fox, Process Technology Programs

Date

APPROVALS:

C. C. Herman, Manager

Date

Process Technology Programs

S.L. Marra, Manager

Date

Environmental \& Chemical Process Technology Research Programs 


\section{EXECUTIVE SUMMARY}

The Savannah River National Laboratory (SRNL) has been investigating the impact of kinetics on nepheline crystallization in high-level nuclear waste (HLW) glasses in order to increase the waste loading to accommodate both anticipated and obligatory requirements. Fundamental nepheline crystallization studies are essential for evaluating the kinetic impacts. SRNL has been collaborating with Clemson University (CU) to measure the low temperature viscosity and experimentally determine the nucleation and crystal growth rates as a function of temperature for simulated HLW glass. The results from a feasibility study indicated the applicability of a technique developed by CU to determine the nucleation and crystal growth rates in a simulated HLW glass was acceptable. This report summarizes the viscosity measurements and the results of a feasibility study and provides the experimental plan for continued collaboration with CU to measure the nucleation and crystal growth rates of select simulated HLW glasses. This research will be used to more accurately identify the temperatures and cooling rates that cause nepheline crystallization in HLW glass so that more robust methods to predict nepheline crystallization can be developed. 


\section{TABLE OF CONTENTS}

2.0 Introduction




\section{LIST OF FIGURES}

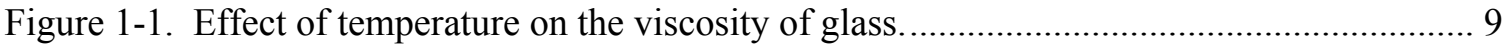

Figure 1-2. Nucleation and crystal growth rates as a function of temperature in glasses. ........... 10

Low temperature viscosity measurements were made on two select glass compositions at CU. The results are summarized in Appendix A. Figure 2-1 shows the measured viscosity data compiled for two glasses in which the high temperature data was measured at SRNL and the low temperature data was measured at CU. Also included in each plot in Figure 2-2 is a viscosity data point at $10^{12} \mathrm{~Pa}-\mathrm{s}$ which, was not measured but, was taken to be the viscosity at the $T_{g}$. The $T_{g}$ was measured using thermogravimetric analysis by CU. The viscosity point extrapolated from the Tg measurements for the EM-N1-19 glass did not fall on the fitted line. Further viscosity measurements are underway to identify the cause of the discrepancy between the fit and that data point................................... 10

Figure 2-3. Viscosity as a function of temperature for glasses measured at SRNL and CU....... 11

Figure 2-4. Hypothetical nucleation and growth curves superimposed on nucleation-like and crystal growth-like thermogravimetric data from Clemson University. 


\section{LIST OF ABBREVIATIONS}

$\begin{array}{ll}\text { CU } & \text { Clemson University } \\ \text { DWPF } & \text { Defense Waste Processing Facility } \\ \text { HLW } & \text { High Level Waste } \\ \text { ND } & \text { Nepheline Discriminator } \\ \text { PCT } & \text { Product Consistency Test } \\ \text { SRNL } & \text { Savannah River National Laboratory }\end{array}$




\subsection{Introduction}

Nepheline crystallization in high-level nuclear waste (HLW) glass is unacceptable because of its known negative impact on the chemical durability as measured by the Product Consistency Test (PCT). ${ }^{1}$ Currently, a compositional constraint, the nepheline discriminator ${ }^{2}$ (ND), is used to avoid nepheline crystallization in HLW glass processed through the Defense Waste Processing Facility (DWPF). ${ }^{3}$ However, the ND is a limiting constraint to achieving projected waste loading increases, particularly for waste streams high in aluminum and sodium. In order to achie ve higher waste loadings while maintaining product acceptability, alternative methods for predicting nepheline crystallization ${ }^{\mathrm{a}}$ in HLW glass are being investigated at the Savannah River National Laboratory (SRNL). Historically, compositional effects have been explored almost exclusively; however, recent research at SRNL is focused primarily on the impact of kinetics ${ }^{\mathrm{b}}$ (rate of mass transport) on nepheline crystallization. In order to accurately predict and, thereby reduce overconservative constraints, nepheline crystallization in HLW glass compositions, the crystallization kinetics need to be understood further. ${ }^{4,5}$ A more complete understanding of the kinetics of nepheline crystallization will ultimately provide a more robust method for predicting and thus, avoiding nepheline crystallization in HLW glass.

In order to utilize the kinetics of nepheline crystallization advantageously, the viscosity of the glass and the nucleation and growth rates as a function of temperature must be known, or at least be able to be approximated. The effect of temperature on viscosity is show in Figure 1-1. Glasses are often described by the fragility of their melt, and the viscosity of a glass in its transition range strongly influences its crystallization.

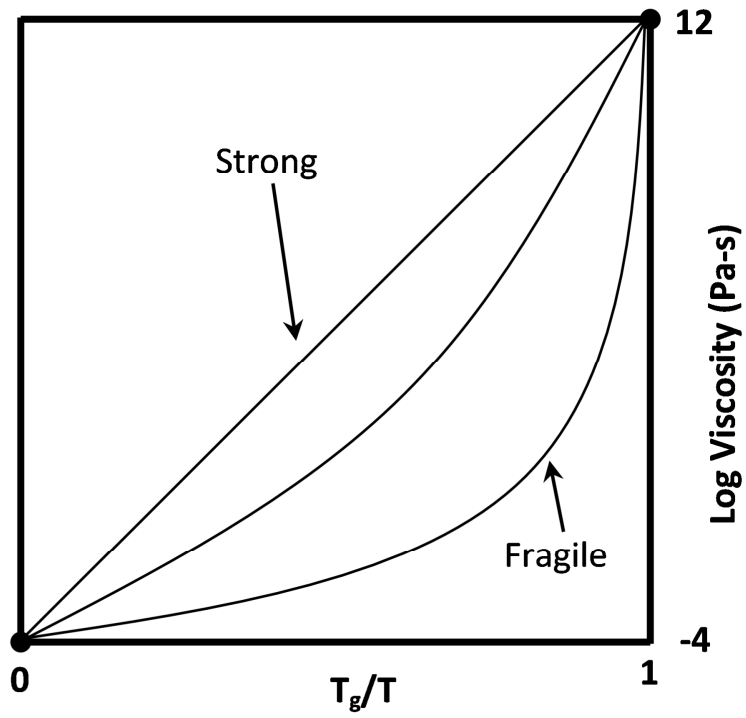

Figure 1-1. Effect of temperature on the viscosity of glass.

\footnotetext{
${ }^{a}$ Crystallization is a general term which in this document refers to both nucleation, the precursor for crystallization, and crystal growth. It should be understood that nucleation is prerequisite for crystallization.

b "Kinetics' refers to the rate of mass transport through the glass transition region. Unlike typical crystalline materials in which the kinetics are relatively fast and crystallization occurs rapidly below the melting temperature, glasses exhibit a transition region in which the kinetics are relatively slow leading to significant changes in crystallization rate with temperature.
} 
The effect of temperature on nucleation and growth rates is shown in Figure 1-2. In this figure, one can see that the temperatures and the cooling rates of a glass will affect the rates of nucleation and crystal growth and in turn the total crystallization.

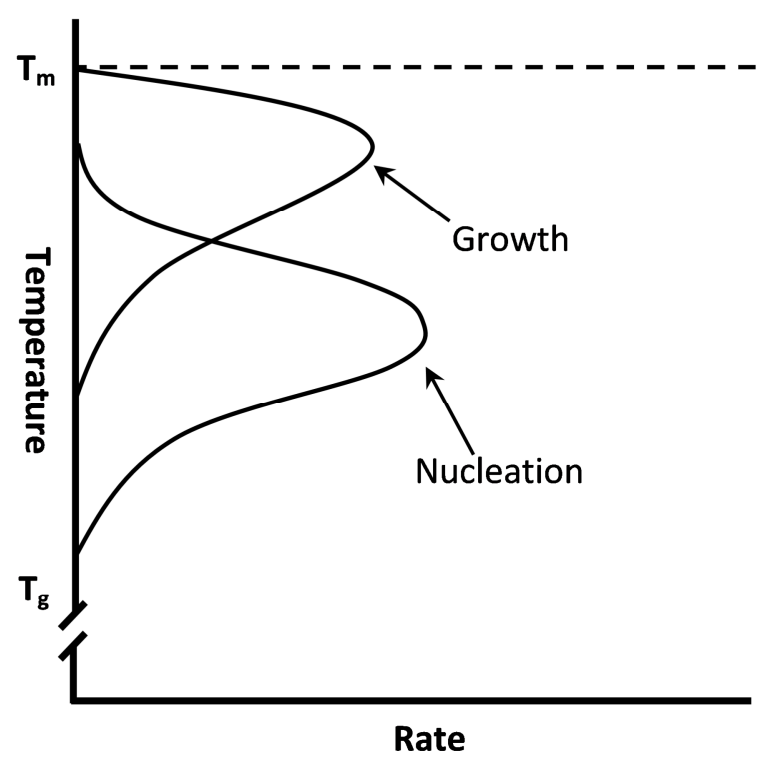

Figure 1-2. Nucleation and crystal growth rates as a function of temperature in glasses.

SRNL is collaborating with Clemson University (CU) to investigate the low temperature viscosity and the nucleation and crystal growth behavior of simulated HLW glasses. The viscosity and nucleation and crystal growth rates (as a function of temperature) will be used to drive computer simulations to investigate nepheline prone regions within a HLW canister during proces sing. This research is being conducted by means of a two-phased approach. Phase I was a feasibility study to determine whether CU could obtain nucleation and crystal growth rates for simulated HLW glasses, the results of which are summarized in this report. The results of the viscosity measurements and nucleation and crystal growth rates are summarized in a report from CU and provided in Appendix A. Upon CU showing adequate results could be obtained in Phase I, a Phase II has been developed to continue experimental studies.

This work was performed for the Department of Energy (DOE) Office of Environmental Management (EM) under the Technology Development and Deployment (TDD) Program Task Plan EM-31 WP-5.1.2. ${ }^{6}$ This is a summary report of phase I and is intended to fulfill the deliverable WP-512-SRNL-01 as identified in the Task Plan.

\subsection{Experimental Plan}

\subsection{Phase I}

Low temperature viscosity measurements were made on two select glass compositions at CU. The results are summarized in Appendix A. Figure 2-1 shows the measured viscosity data compiled for two glasses in which the high temperature data was measured at SRNL and the low temperature data was measured at CU. Also included in each plot in Figure 2-2 is a viscosity data point at $10^{12} \mathrm{~Pa}$-s which, was not measured but, was taken to be the viscosity at the $\mathrm{T}_{\mathrm{g}}$. The $\mathrm{T}_{\mathrm{g}}$ was measured using thermogravimetric analysis by $\mathrm{CU}$. The viscosity point extrapolated from 
the Tg measurements for the EM-N1-19 glass did not fall on the fitted line. Further viscosity measurements are underway to identify the cause of the discrepancy between the fit and that data point.

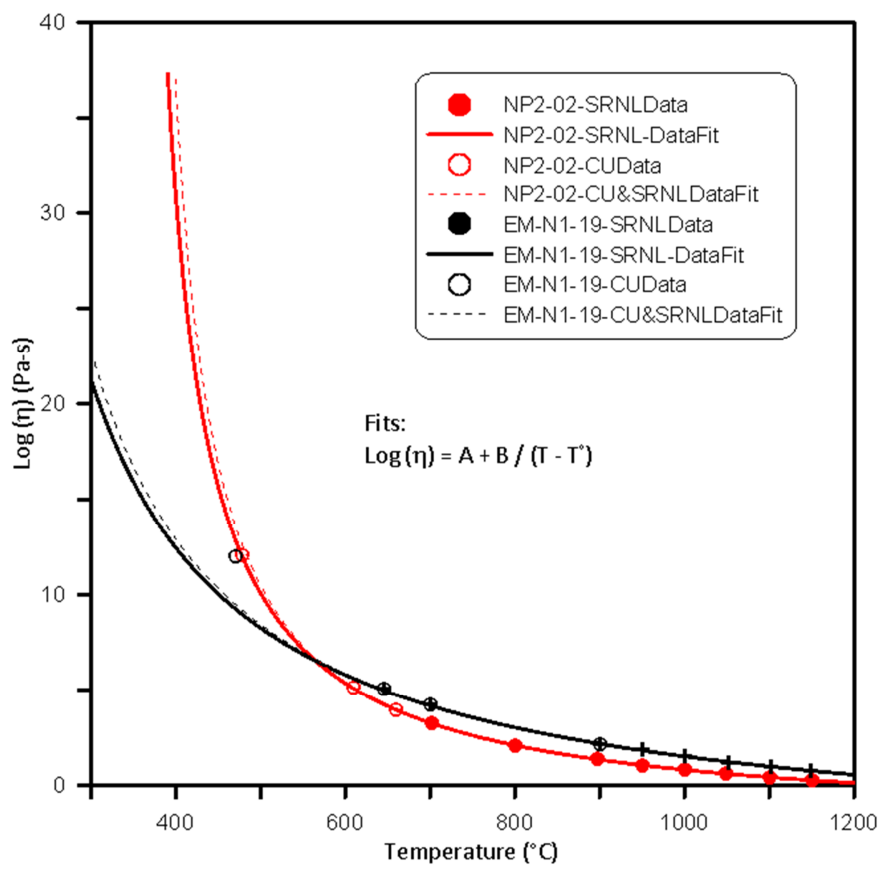

Figure 2-3. Viscosity as a function of temperature for glasses measured at SRNL and CU.

Nucleation and crystal growth studies are typically time consuming and difficult to perform successfully. CU has developed a technique that uses traditional thermal analysis instrumentation to generate nucleation-like and crystal growth-like curves. ${ }^{\mathrm{a}}$ In this technique, crystal growth and nucleation rates are extracted from phase transitions (crystallization) identifiable in the thermogravimetric data. The identity of the crystalline phases can be obtained by further analysis of the sample. Because Phase I was a feasibility study to determine whether the technique developed at CU was acceptable, the identity of the phases was not determined. The initial results of a CU feasibility study are provided in Appendix A. Figure 2-1 shows the raw data graphically in which hypothetical curves have been drawn through the data points. Indeed, two distinct curves appear to be identifiable. Although the phase associated with the data points has yet to be determined, the temperatures of the nucleation-like and growth-like curves are within the expected range. In Phase I of this study, it was determined that the method could be used to investigate nucleation and crystal growth rates in simulated HLW glasses.

It should be reiterated that Phase I was a feasibility study only to determine whether the methodology was practical to HLW glasses. Phase II is designed to apply the methodology demonstrated in Phase I to obtain nucleation and crystal growth rates in addition to detailed characterization of the sample to determine phase identity(s) of the crystallization.

\footnotetext{
${ }^{a}$ These curves are not generated from direct measurement of the nucleation and growth rates and therefore should not be termed as such, thus the clarifier like.
} 
SRNL-STI-2011-00549

Revision 0

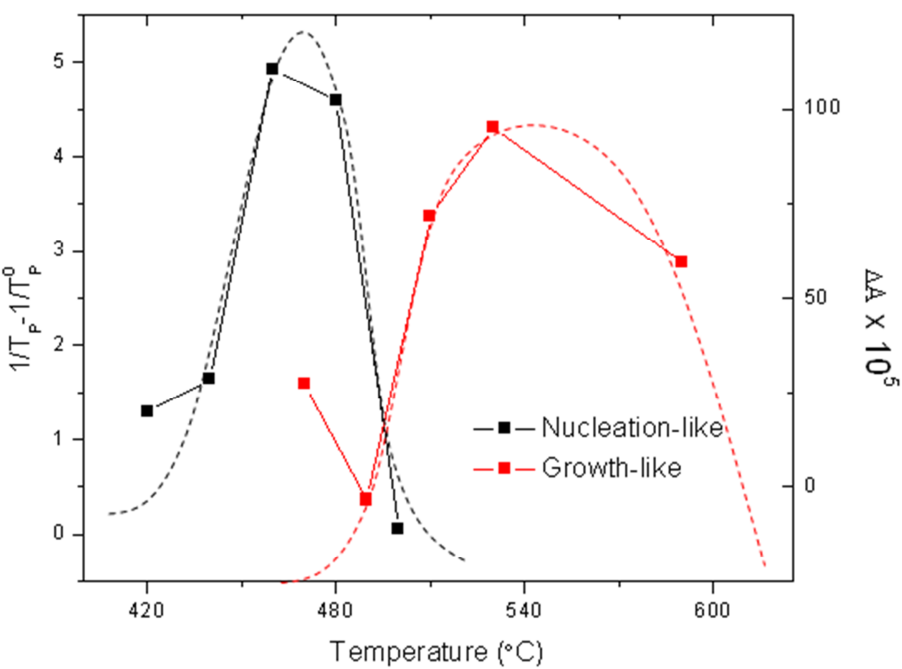

Figure 2-4. Hypothetical nucleation and growth curves superimposed on nucleation-like and crystal growth-like thermogravimetric data from Clemson University.

\subsection{Phase II}

In the next phase of experiments, $\mathrm{CU}$ will continue to measure low temperature viscosities and the nucleation-like and crystal growth-like curves for selected simulated HLW glasses melted at SRNL. These glasses will be selected from a subset of glasses for which crystallization data have been measured. ${ }^{4}$ In addition, more detailed characterization post-thermal analysis will be conducted at both SRNL and CU to determine the crystalline phases present, the type (heterogeneous or homogenous) of crystallization, and any interfacial effects.

Ultimately, these data will lead to a more complete understanding of the way in which nepheline crystallizes in HLW glasses. Then, the results can be used to drive precise experiments to develop a more encompassing method of predicting nepheline crystallization in HLW glass.

\subsection{Summary}

This report summarizes a feasibility study to demonstrate the ability for $\mathrm{CU}$ to measure low temperature viscosity and the applicability of a technique that $\mathrm{CU}$ developed to measure nucleation and crystal growth rates as a function of temperature in HLW Glasses. Future experimental plans for further studies to be conducted by SRNL in collaboration with CU are also presented. The intention of this research is to gain an understanding of the fundamental crystallization behavior present in HLW glasses. Subsequently, a more complete knowledge of the factors affecting nepheline crystallization in HLW glass can be identified and ultimately glass formulations and processing parameters can be optimized, beyond the current limits, to avoid nepheline crystallization in HLW glass. 


\subsection{References}

1. "Standard Test Methods for Determining Chemical Durability of Nuclear, Hazardous, and Mixed Waste Glasses and Multiphase Glass Ceramics: The Product Consistency Test (PCT)," ASTM C-1285-02 (2002).

2. H. Li, J. D. Vienna, P. Hrma, D. E. Smith and M. J. Schweiger, "Nepheline Precipitation in High-Level Waste Glasses: Compositional Effects and Impact on the Waste Form Acceptability," Materials Research Soc. Symp. Proc., 465 pp. 261-68, (1997).

3. T. B. Edwards, D. K. Peeler and K. M. Fox, "The Nepheline Discriminator: Justification and DWPF PCCS Implementation Details," U.S. Department of Energy Report WSRCSTI-2006-00014, Aiken, SC (2006).

4. J. W. Amoroso, "The Impact of Kinetics on Nepheline Formation in Nuclear Waste Glasses," US Department of Energy Report SRNL-STI-2011-00051, Savannah River National Laboratory, Aiken, SC (2011).

5. J. W. Amoroso, "Computer Modeling of High-Level Waste Glass Temperatures Within DWPF Canisters During Pouring and Cool Down," US Department of Energy Report SRNL-STI-2011-00546, Savannah River National Laboratory, Aiken, SC (2011).

6. EM-30 Technology Development and Deployment (TDD) Program Task Plan, "Task Plan for WP-5 Task 5.1.2 Advanced Silicate Glass Development and Demonstration," WP5-5.1.2-FY2011 Revision 0, (2011). 
SRNL-STI-2011-00549

Revision 0

Appendix 
Interim Report on Viscosity and Crystal Growth Studies

Subcontract-Grant \#SC0276

"Nucleation and Crystallization Studies"

Submitted by:

Dr. Jonathan David Musgraves, PI

School of Materials Science and Engineering

Clemson University

161 Sirrine Hall

Clemson, South Carolina 29634-0971

September 12, 2011 
Objectives: The goal of the currently funded effort is for Clemson to provide technical support to Savannah River National Lab (SRNL) employees conducting research on the crystallization properties of a number of candidate glasses. Specifically, the Clemson effort is directed toward measurement of the viscosity as well as the nucleation and growth characteristics of these glasses. This interim report details the results obtained thus far regarding viscosity measurements of the glasses NP2-02 and EM-N1-19, as well as the results of the feasibility study for crystal nucleation and growth characterization in the NP223 glass.

Experimental Methods: The viscosity of the NP2-02 and EM-N1-19 glasses was measured using the Parallel Plate Viscometry (PPV) technique. Samples of the candidate glasses were fabricated by coredrilling cylinders of glass from the bulk pieces provided by SRNL. Following drilling the cylinders were cut with a diamond saw to produce samples with a final geometry of $6 \mathrm{~mm}$ in diameter and $4 \mathrm{~mm}$ in height. Both cylinder endfaces were optically polished before the test.

Viscosity was measured using a PPV 100 instrument from Orton Ceramic Foundation. The sample was placed between the parallel plates, with a platinum film used at the glass/ steel interface to prevent sticking. The system was then heated at a rate of $5{ }^{\circ} \mathrm{C} /$ minute to the final target temperature, and the deflection of the plates recorded as a function of temperature. From this deflection, the viscosity of the glass was calculated via ASTM C-1351M, using the following equation:

$$
\eta=2 \pi \frac{M g h^{5}}{30 V\left(\frac{d h}{d t}\right)\left(2 \pi h^{3}+V\right)(1+\alpha T)}
$$

where $\eta$ is the viscosity in Pa s, $M$ is the applied load, $g$ is the acceleration due to gravity, $h$ is the sample height at time $t, V$ is the sample volume, $d h / d t$ is the compression rate, and $\alpha$ is the coefficient of thermal expansion of the glass.

The semi-quantitative, nucleation-like curve of the NP2-23 glass was determined using the method proposed by Marotta et al. [1]. The maximum of the exothermic peak was measured using a heating rate of $5{ }^{\circ} \mathrm{C} /$ min using a Differential Thermal Analyzer (DTA) with $\left(T_{p}\right)$, and without $\left(T_{p}{ }^{\circ}\right)$ an isothermal hold for $30 \mathrm{~min}$. at $\mathrm{T}$, a potential nucleation temperature (i.e., a temperature in the vicinity of the suspected nucleation maxima). The nucleation-like curve $\left(I_{0}\right)$ is then obtained by plotting $\left(1 / T_{p}-1 / T_{p}\right.$ $\left.{ }^{0}\right)$ as a function of $\mathrm{T}$, the potential nucleation temperatures, as shown in Eq. 2:

$$
\operatorname{Ln}\left(I_{0}\right)=\frac{E_{C}}{R}\left(\frac{1}{T_{P}}-\frac{1}{T_{P}^{0}}\right)
$$

where $I_{0}$ is the steady state nucleation rate and $E_{c}$ is the activation energy for crystallization which represents the minimum amount of energy to initiate a reaction.

The growth-like curve of the NP2-23 glass was determined using the technique proposed by Ray et al. [2]. Thirty to fifty milligrams of glass powder was heated in the DTA from room temperature to a 
potential growth temperature (i.e., a temperature in the vicinity of the growth rate maxima) at a heating rate of $5{ }^{\circ} \mathrm{C} / \mathrm{min}$. After $5 \mathrm{~min}$ at this temperature, the temperature was decreased to a temperature lower than $T_{g}$ and the glass powder was stabilized at this temperature for 5 min. Finally, the temperature was ramped up to a temperature higher than the crystallization temperature using a $5^{\circ} \mathrm{C} /$ min heating rate. The area of the exothermic peak $\left(A_{T}\right)$ was then measured. The same experiment was reproduced using various growth temperatures and the growth-like curve was obtained by plotting $\triangle A=A-A_{\tau}$ as a function of the growth temperature (with $A$ the exothermic peak area of a glass powder which was not heat treated at any potential growth temperature for $5 \mathrm{~min}$ ).

Results: The viscosity curves obtained for the NP2-02 and EM-N1-19 glasses are shown below in Figure 1 , with the data obtained from the PPV shown at elevated temperatures for both glasses. In order to approximate the viscosity/temperature profile of the glasses across a wider temperature range, the glass transition temperature $\left(T_{g}\right)$ of each glass, measured in a calorimeter, was assigned a viscosity of $10^{12} \mathrm{~Pa} \mathrm{~s}$, in accordance with literature [3]. The addition of this point permits the fitting of the full viscosity curve using the empirical equation developed by Vogel, Fulcher, and Tamann (VFT) [4]:

$$
\log _{10} \eta=A+\frac{B}{T-C}
$$

where $A, B$, and $C$ are left as fitting parameters. The values obtained for these parameters through the best fit of the data are shown in Table I.

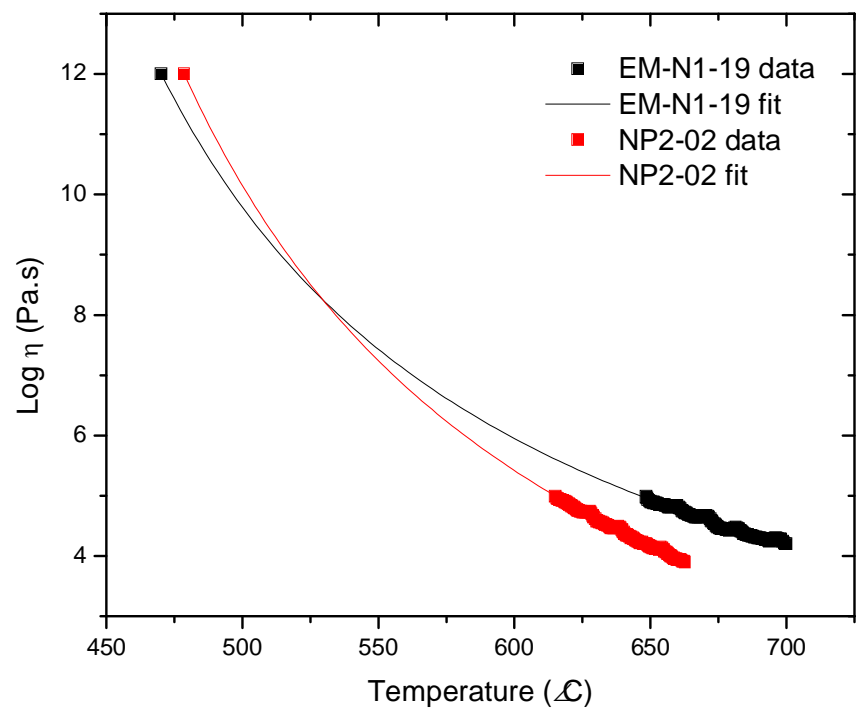

Figure 1. Viscosity/temperature profiles of the NP2-02 and EM-N1-19 glasses, fit with Eq. 3. 
Table I. VFT parameters obtained from VFT viscosity fit.

\begin{tabular}{|c|c|c|c|}
\hline Glass Type & $\underline{\mathbf{A}}$ & $\underline{\mathbf{B}}$ & $\underline{\mathbf{C}}$ \\
\hline EM -N1-19 & -0.54566 & 1748.34053 & 330.8475 \\
\hline NP2-02 & -2.52909 & 2192.71036 & 322.00895 \\
\hline
\end{tabular}

Examples of the raw thermal data obtained from the DTA indicating the relevant quantities used to produce the nucleation- and growth-like curves of the NP2-23 glass are shown in Figures 2 and 3. Figure 2 shows the shift of the maximum of the exothermic peak as a function of heat treatment. A 30 minute hold at a test temperature of $460{ }^{\circ} \mathrm{C}$ leads to a shift in the temperature position of this peak from $745^{\circ} \mathrm{C}$ to $718{ }^{\circ} \mathrm{C}$. Figure 3 shows the change in area of the exothermic peak as a function of heat treatment, with a 5 minute hold at a test temperature of $530{ }^{\circ} \mathrm{C}$ decreasing this area from 234 to 139 .

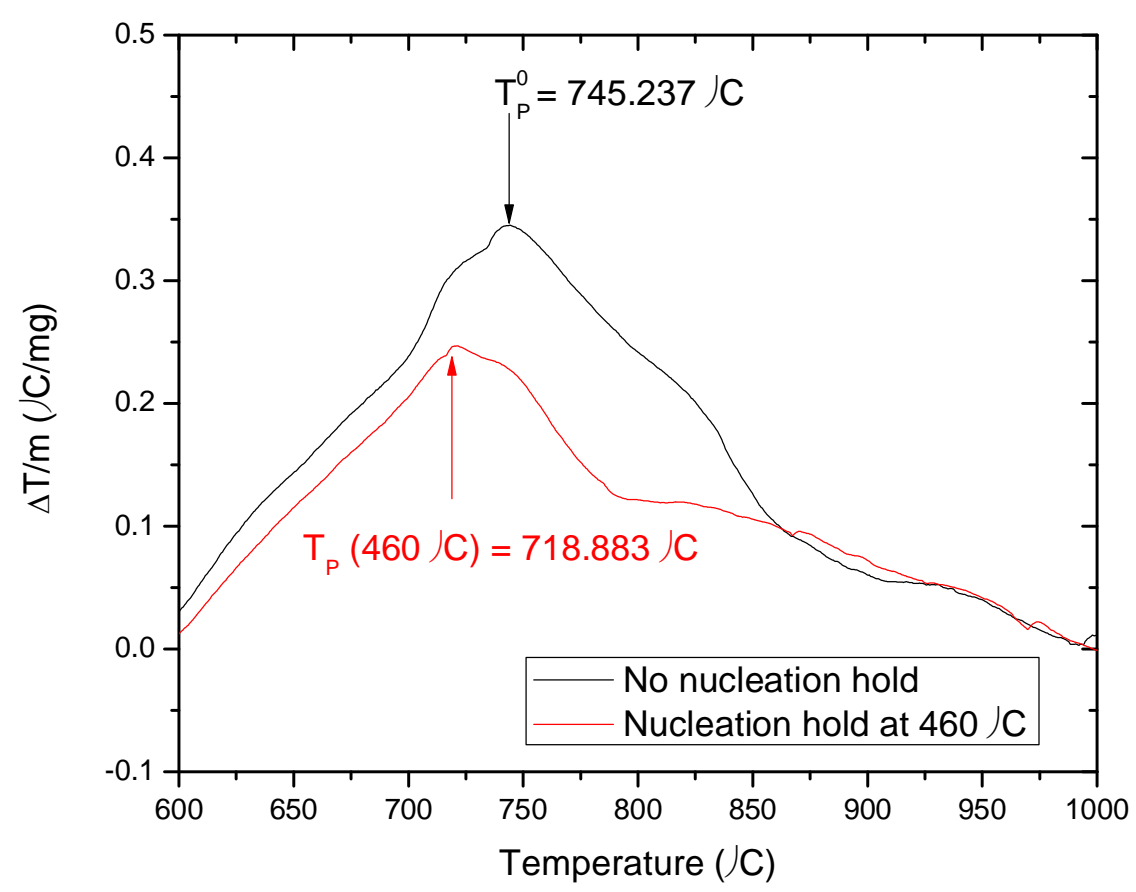

Figure 2. Exothermic peak shift used to calculate the nucleation-like curve of NP2-23 glass. 


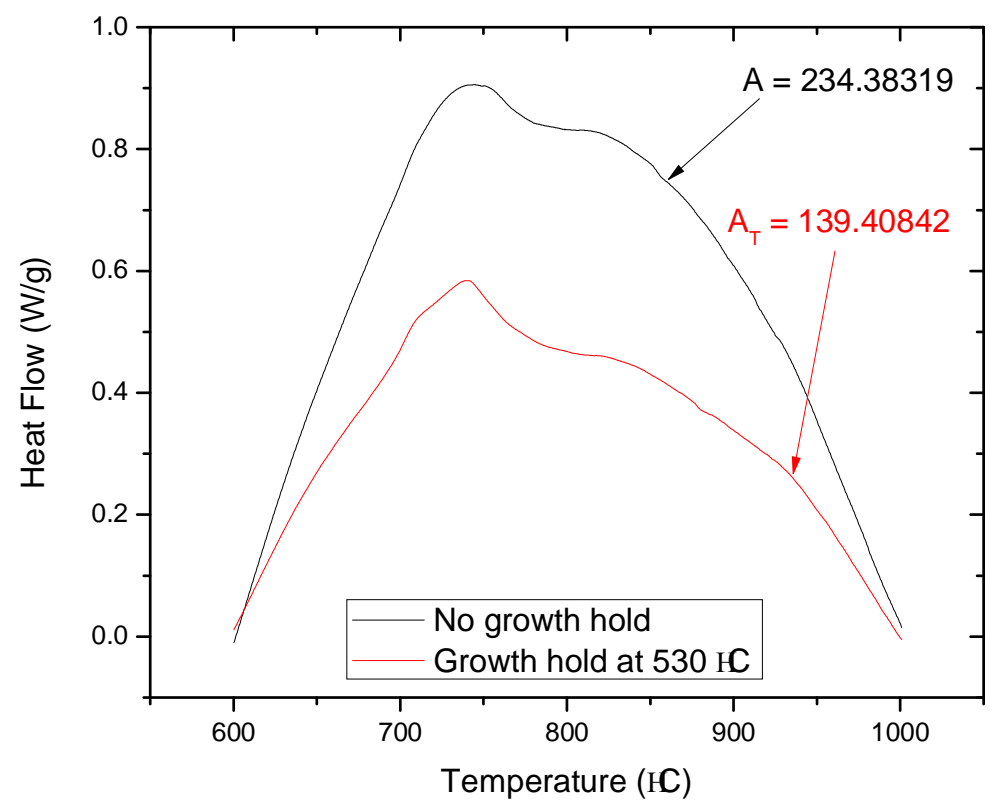

Figure 3. Change in exothermic peak area used to calculate the growth-like curve of NP2-23 glass.

Figure 4 shows the calculated nucleation- and growth-like curves of the NP2-23 glass, with data spaced every $20^{\circ} \mathrm{C}$, corresponding to individual tests at each of these temperatures.

NP2-23 Glass

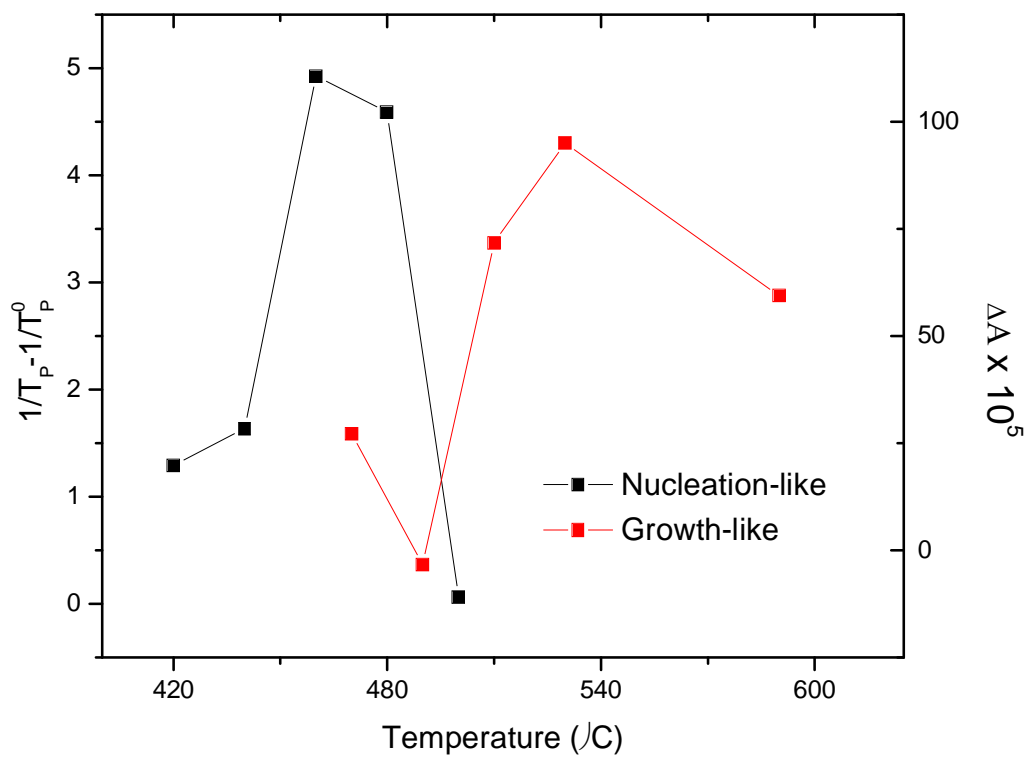

Figure 4. Nucleation- and growth-like curves for the NP2-23 glass. 
This figure represents a successful test of the feasibility of using these calorimetric techniques to studying the nucleation and growth behavior of these glasses. Clear evidence is seen of separated nucleation and growth curves, with an $80^{\circ} \mathrm{C}$ window between the maxima of $460{ }^{\circ} \mathrm{C}$ (nucleation) and $540{ }^{\circ} \mathrm{C}$ (growth). This result is encouraging in regards to the team's ability to control the crystallization behavior in these glasses (with suitable temperature control of the entire bulk glass volume); additionally well separated nucleation and growth regimes are critical in maintaining amorphous structure in the glass network and avoiding undersirable crystallite formation during cooling (through the nucleation region) or after.

\section{References Cited:}

1. A. Marotta, A. Buri, and F. Branda, "Nucleation in glass and differential thermal-analysis," J. Mater. Sci. 16, 341-344 (1981).

2. C. S. Ray, K. S. Ranasinghe, and D. E. Day, "Determining crystal growth rate-type of curves in glasses by differential thermal analysis," Solid State Sci. 3, 727-732 (2001).

3. L. M. Martinez and C. A. Angell, "A thermodynamic connection to the fragility of glass-forming liquids," Nature 410, 663-667 (2001).

4. I. Avramov and A. Milchev, "Effect of disorder on diffusion and viscosity in condensed systems," J. Non-Cryst. Solids 104, 253-260 (1988). 